\title{
Land Use and Social Economic Transformation in Colomadu Sub-District
}

\section{Ratna Kusumaningrum ${ }^{1}$}

Diterima : 26 Desember 2014

Disetujui : 9 Januari 2015

\begin{abstract}
Urbanization turns out to be the most popular term use now to describe urban development and growth. In the process of urban development, sprawl is the stage when urban cannot provide the basic need of its inhabitant and then start to exploit the neighborhood area. The most obvious condition of urban sprawl is when the activities transforming from farm to non-farm activities (Zaninetti, 2006). Then turn the physical characteristic of the area and create a mixture of rural and urban land use characteristic. Area with this characteristic called as transitional area (Douglas, 2006 stated in Huang, Wang, Budd, 2009), peri-urban interface (Dutta, 2012) or desakota by Mcgee. As one of Solo City peryurban area, Colomadu Sub district has been transforming both in land use and social economic characteristic. Colomadu is a unique area where administratively state as part of Karanganyar District but geographically located closer toward Solo City. So that, how is the land use and socio economic transformation there?
\end{abstract}

Key words: peri-urban, land use, socio-economic, transformation

\begin{abstract}
ABSTRAK
Urbanisasi adalah istilah yang sering disebutkan ketika dihadapkan pda pembahasan perkembangan kota dan petumbuhannya. Pengembangan kota sendiri tidak dapat dipisahkan dari sprawl atau pemekaran kota, dimana kota sudah tidak mampu menyediakan kebutuhan dasar bagi masyarakatnya sehingga kemudian menyebabkan area sekitarnya mulai terdampak dan tereksploitasi. Kondisi yang paling nampak ketika melihat pemekaran kota ada transformasi ekonomi masyarakat dari basis pertanian menjadi non pertanian (Zaninetti, 2006). Pemekaran yang terjadi juga mengubah karakteristik fisik kawasan tersebut, yang kemudian disebut sebagai kawasan transisi (Douglas, 2006 dalam Huang, Wand, dan Budd, 2009), peri-urban interface (Dutta, 2012), dan juga Desakota oleh McGee. Sebagai salah satu kawasan peri-urban dari Kota Solo, Kecamatan Colomadu telah mulai bertransformasi dalam sosial ekonomi dan guna lahan. Colomadu merupakan kawasan yang cukup unik, dikarenakan kecamatan ini secara adminitratif adalah bagian dari Kabupaten Karanganyar. Namun, secara geografi terletak lebih dekat dengan Kota Solo. Sehingga kemudian muncul pertanyaan bagaimana transformasi yang terjadi di Colomadu dalam sosial ekonomi dan guna lahan?
\end{abstract}

Kata kunci: peri-urban, guna lahan, sosial, ekonomi, transformasi

\footnotetext{
${ }^{1}$ Mahasiswa Magister Pembangunan Wilayah dan Kota, Undip, Semarang, Jawa Tengah Kontak Penulis : kusumaningrumratna@gmail.com
} 


\section{INTRODUCTION}

Urbanization and urban sprawl are two common phenomenona in the urban development. United nation in 2010, stated that 50\% of world population live in urban area and it will reach 69.6\% in 2050 (Wu and Zhang, 2011). Both phenomenons have influenced the development and transformation of peripheral area, such as physical, social economy, cultural, morphological, and functional transformation (Brook and Davila, 2000; Dupont, 2004 stated in Dutta, 2012).

Colomadu Sub district is one of Solo peri-urban which is located in the northern part of Solo City. This sub district is unique although this area administratively stated as part of Karanganyar District, but geographically it is located closer toward Solo than Karanganyar itself. Thus, thus, it can be assumed that Solo City might have greater role in Colomadu's development rather than Karanganyar district. It has the definition of peri urban with heterogeneous social economic condition and mix characteristic of rural and urban area just like peri urban definition stated by McGee in Narrain and Nischal, 2007.

In term of land use characteristic, formerly this area is dominated by agriculture land that produces rice, corn and sugar cane, but currently the number of agriculture land decrease continuously. It occurs due to the development of residential estate and settlement. The number has been decreasing continuously. Colomadu Sub district is not the only one and the most developed peri-urban area of Solo City. Solo Baru and Kartasura, which are part of Sukoharjo District, are two most urbanized area around Solo City. Both of them are highly developed compared to Colomadu. Solo Baru and Kartasura aredominated by commercial activities but Colomadu development dominated by residential area. The invasion of residential estate by private developer had been causing not only environmental and land use transformation but also social economic transformation. The number of farmer keeps decreasing day by day. The questionnaire data result shows that there is $80 \%$ economic transformation from farm to nonfarm activities with only $3 \%$ farmer left from total number of respondents in Colomadu.

Thus, this research will try to gives more information and understanding about Colomadu as one of the most potential peri-urban now. Then the questions that arise are how are the land use and socio economic transformation and development in Colomadu Sub districtespecially related to the farm to nonfarm shift? This question will be the main point for further observation in this study.

\section{RESEARCH METHODOLOGY}

Research methodology that will be used in this research is mixed method between the use quantitative descriptive method to determining research variables trough literature and previous research review. Questionnaire is the main instrument in this study, although purposive interview will also be held to support the analysis later in the report. The variables used in this report include urban growth, urban sprawl, urbanization, rural-urban interface characteristic, land use transformation, and social economic transformation. Secondary data, especially statistical data, will be important in order to understand the growth and transformation.Interview data that will be delivered in qualitative descriptive method is essential in analyzing the social and economic transformation. In this quantitative research, questionnaire is essential. The number of sample taken are important to support the hypothesis that already made. There are many ways to formulate the number of sample in the 
research activities, but the sample formula used here is based on Sukandarrumidi statistical formula (2004:56) took from Artiningsih, 2011. Here is the formula,

$$
\mathrm{n}=\frac{\lambda^{2} \cdot \mathbf{N} \cdot \mathbf{P} \cdot \mathbf{Q}}{\mathrm{d}^{2}(\mathbf{N}-1)+\lambda^{2} \cdot \mathbf{P} \cdot \mathbf{Q}}
$$

$\begin{array}{lll}\mathrm{N} & =\text { Population size } & \\ \mathrm{d} & =\text { error estimation } & =10 \%=0,1 \\ \lambda & =\text { Reliability } & =95 \%=1.96 \\ \mathrm{P} & =\text { Proportion } & =0.5 \\ \mathrm{Q} & =(1-\mathrm{P}) & =0.5\end{array}$

So the sample estimation would be,

$$
\begin{aligned}
\mathrm{n} & =\frac{(1,96)^{2} \cdot 72760 \cdot 0,5 \cdot 0,5}{(0,1)^{2} \cdot(72760-1)+(1,96)^{2} \cdot 0,5 \cdot 0,5} \\
& =96
\end{aligned}
$$

Purposive interview methodology requires some basic criteria to choose the right respondent.It is also important to avoid time wasting and data error.

\section{GENERAL OVERVIEW OF COLOMADU SUB-DISTRICT}

Colomadu,it located $21.6 \mathrm{~km}$ from the district capital, is one of developed sub-district in Karangnyar. This sub-district located in the west side of Solo City.This This sub-district covers 1564.4 ha in total that consists of 520 ha wetlands and 1044.2 ha dry land. The biggest area in this sub-district is Malangjiwan village by 206.4 ha, followed by Gedongan Village 179.3 ha, and the third one is Blulukan village with 163.9 ha area. Gajahan and Paulan Village are the smallest of all with 72.6 ha and 97.7 ha. From the total area of Colomadu, 895.9 ha is used as built up area, and 520 ha is used as a wetland area supporting farming activities but it is gradually decreasing day by day. There is no savanna, forestry and plantation in this area.

The research area will describe in map of Colomadu as below:

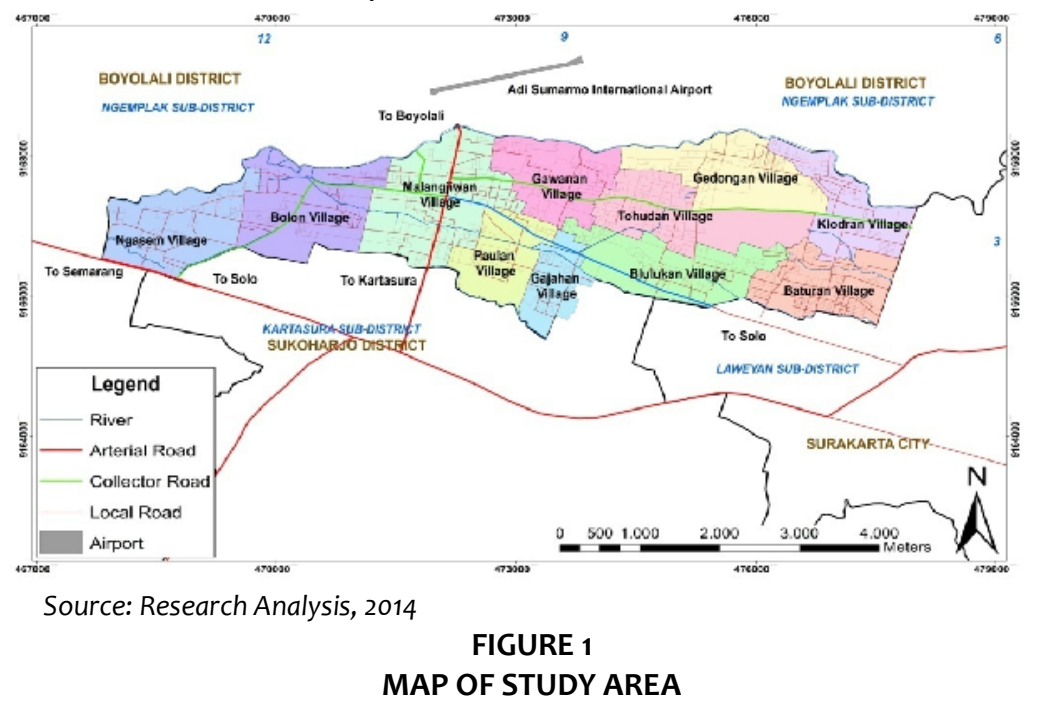


There are four important region and districts related with Colomadu Sub-districts and its development. In the existing map, we can see administratively this sub-district is part of Karangnyar District, but it is surrounded by other cities and districts which can be seen in the maps below.

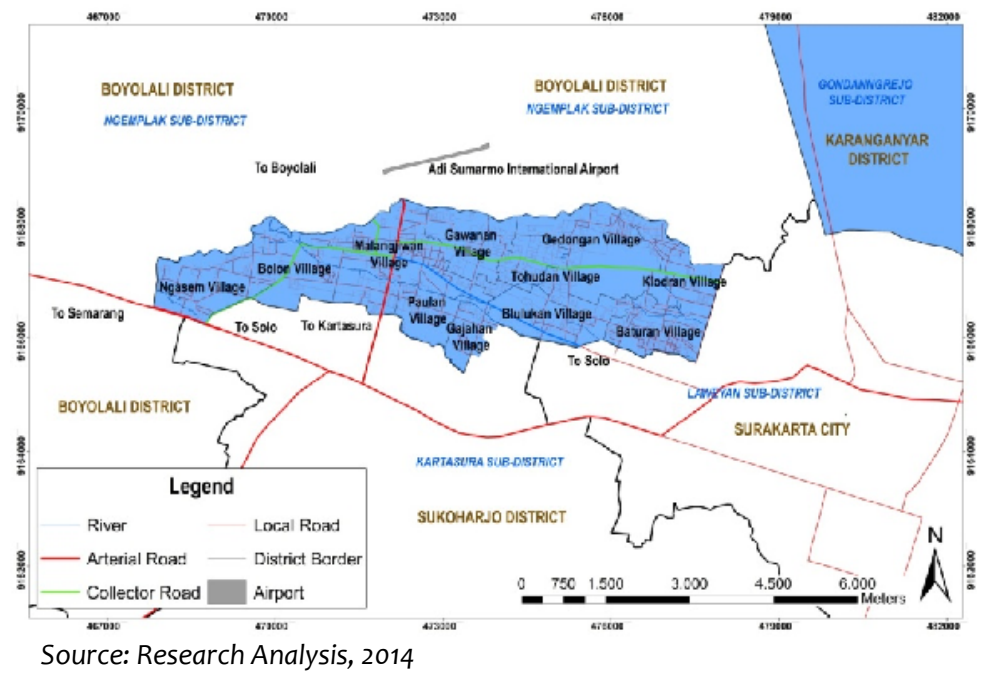

FIGURE 2

COLOMADU SUB DISTRICT SURROUNDED BY THREE DIFFERENT DISTRICTS

\section{ANALYSIS}

\section{Land Use Transformation Analysis}

As one of the direct borders of Solo City, it has peri-urban characteristics. It has the characteristic that is called the urban fringe by Narain and Nischal (2007). The urban fringe means transitional characteristic between rural and urban area, where social, environment, and economic aspect interactions found. This sub-district is a transitional area between urban Solo and Rural Boyolali District. Colomadu in-between them has transitional characteristic of those three aspects of rural and urbanarea It shares both farm and nonfarm activities of its inhabitants. It also shares diversed land use in a mixture of rural land use and urban characteristic use like commercial and settlement use. Moreover because of its intense influence of the Solo urban area, this area is included in a direct impact zone. The people movement is high especially because of the existence of Adi Sumarmo International Airport in the north of Colomadu.

Population growth here has brought urbanization and transformation in land use and socioeconomical aspect. Population growth of Colomadu is quite fast. It can be identified by the population number in below map. 


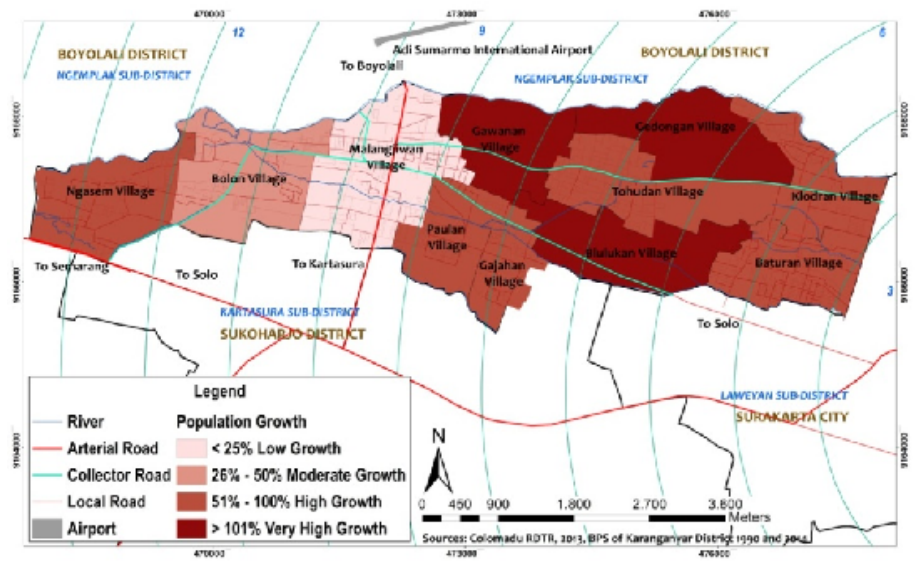

Source: Research Analysis, 2014

\section{FIGURE 3 \\ POPULATION GROWTH OF COLOMADU SUB-DISTRICT IN 1990 TO 2013}

The total number of permanent houses is rising in only ten years. As the only sub-district that connects Solo City and its one and only international airport in Boyolali District, Colomadu has been advantaged as the area to develop settlements and to do commercial activities. The biggest street that connects Solo, Colomadu and Adi Sumarmo International Airport is Adi Sucipto Street. Here in Adi Sucipto the concentration of commercial activities can be found. On the other hand, high availability of land in Colomadu attracts many investors to come and develop new settlements and houses. It does not only attract big investors but also small and petty investors that build less than 40 houses. Today, the housing development trend is dominated by petty or small developers while in the past the early developer residential estate are built by big developer which peovided more than 40 houses.

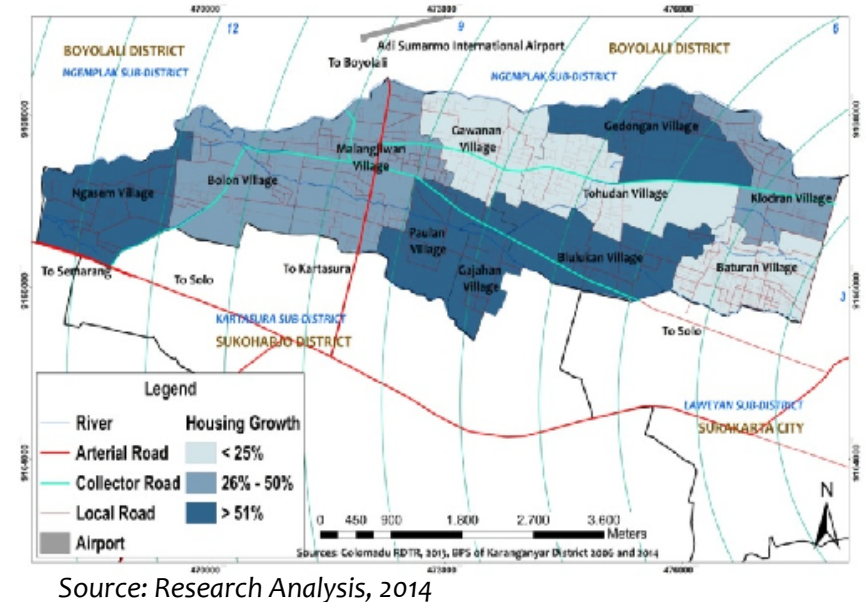

FIGURE 4

HOUSING NUMBER GROWTH IN 2006 TO 2013

The blue color map above is the housing growth map from 2006 to 2013 . There are three category of housing growth here. The first one is the low housing growth with less than $25 \%$ growth. The second one is moderate housing growth with $26-50 \%$ growth in total, and the last category is high housing growth with more than $51 \%$ growth in seven years. The result of the 
compilation is that although Malangjiwan and Baturan Village have the highest number of houses but the growth seems to be moderate and low in between 2006 to 2013. The growth is quite similar to the previous years. This means that both villages had early development in comparison to other village. The villages with the high housing growth arePaulan, Gajahan, Blulukan, Gedongan and Ngasem Village. The moderate housing growth are Malangjiwan, Bolon and Klodran Village. And last but not least the low housing growth areBaturan, Tohudan, and Gawanan Village. This result could be different on different period of time. In 1994, for example,based on the land central bureau data, the highest transformation village is Blulukan Village with more than $30.000 \mathrm{Ha}$ land transformed into non-farm uses. On the other hand, in the 2013 there is no village with more than $30.000 \mathrm{Ha}$ transformation but there are five villages with 15.000 to 30.000 Ha transformation.

TABLE 1

COLOMADU SUB-DISTRICT LAND USE DATA

\begin{tabular}{|r|r|r|rr|r|}
\hline Land Use & $\mathbf{1 9 9 0}$ & $\mathbf{2 0 0 3}$ & $\mathbf{2 0 0 6}$ & $\mathbf{2 0 1 1}$ & $\mathbf{2 0 1 3}$ \\
\hline Wet Land & 840.3 & 716.6 & 547.6 & 520 & 486.6 \\
\hline Built-up & 583.3 & 767.6 & 865.9 & 895.9 & 931.3 \\
\hline Farm & 81.9 & 60.6 & 67.8 & 65.4 & 65.4 \\
\hline Savana & 0.32 & 0 & 0 & 0 & 0 \\
\hline Pond & 2.9 & 2.5 & 2.7 & 2.7 & 2.7 \\
\hline Forestry & 0 & 0 & 0 & 0 & 0 \\
\hline Plantation & 4.7 & 4.6 & 0 & 0 & 0 \\
\hline \multicolumn{7}{|c|}{ Others } \\
Sources: BPS of Karanganyar District, 1990,2003, 2006, 2011, and 2013 \\
\hline
\end{tabular}

Compared to the 1990's, the land characteristics and uses in the 2000's have been transforming as the result of urbanization and exploitation of settlement. The domination has completely shifted from wet land to built-up area. Today, the land has urban characteristic rather than rural. The plantation use has completely gone just like savanna in 2003's data. Then, when it is compared to Karanganyar land use data, the statistic shows the real tendency of development compared to other sub-districts. As one of two sub-districts having more builtup use than farm land, Colomadu is quite dense. It was the densest sub-district in Karangayar as proven by population number statistical datain 2012. It is stated that the density of Colomadu reached 4688 people per $\mathrm{km} 2$, the highest one compared to other sub-districts.

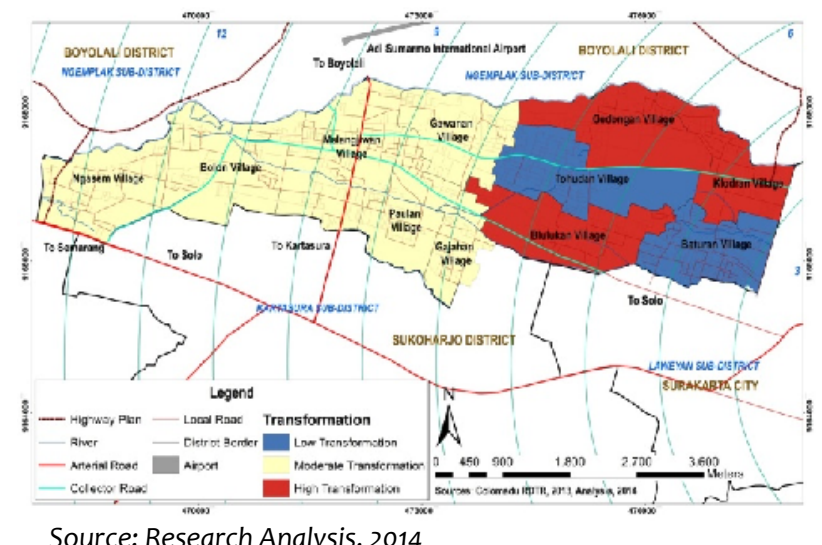

Source: Research Analysis, 2014

FIGURE 5 


\section{LAND USE TRANSFORMATION MAP OF COLOMADU IN 2006 TO 2013 \\ TABLE 2 COLOMADU SUB-DISTRICT LAND USE TRANSFORMATION TYPOLOGY}

\begin{tabular}{|c|c|c|c|c|}
\hline Typology & $\begin{array}{c}\text { Population } \\
\text { Growth }\end{array}$ & $\begin{array}{l}\text { Housing } \\
\text { Growth }\end{array}$ & $\begin{array}{c}\text { Farm to Non-Farm } \\
\text { Transformation }\end{array}$ & Village \\
\hline $\begin{array}{l}\text { Low } \\
\text { Transformation }\end{array}$ & $\begin{array}{l}\text { There are three } \\
\text { typologyes in } \\
\text { population } \\
\text { growth low, } \\
\text { moderate and } \\
\text { high population } \\
\text { growth. The } \\
\text { lowest one is } \\
\text { population } \\
\text { growth that has } \\
\text { not more than } \\
25 \% \text { percentage } \\
\text { of growth from } \\
2006 \text { to } 2013 .\end{array}$ & $\begin{array}{l}\text { The same } \\
\text { Typology } \\
\text { happened in } \\
\text { housing } \\
\text { number } \\
\text { growth. Low } \\
\text { level of } \\
\text { housing } \\
\text { number } \\
\text { growth has } \\
\text { less than } 25 \% \\
\text { growth in } \\
\text { housing } \\
\text { number } \\
\text { since } 2006 .\end{array}$ & $\begin{array}{l}\text { The same typology also } \\
\text { given to this variable. } \\
\text { Low transformation } \\
\text { means land use swift } \\
\text { from farm to non farm } \\
\text { uses that consider } \\
\text { being less than } 25 \% \text { in } \\
2006 \text { to } 2013 . \text { It all } \\
\text { based on quantitative } \\
\text { data given by } \\
\text { Karanganyar District } \\
\text { central bureau. }\end{array}$ & $\begin{array}{ll}\text { - } & \text { Tohudan } \\
\text { Village } \\
\text { - } \quad \text { Baturan } \\
\text { Village }\end{array}$ \\
\hline $\begin{array}{l}\text { Moderate } \\
\text { Transformation }\end{array}$ & $\begin{array}{l}\text { This category } \\
\text { has total } 25 \% \text { to } \\
50 \% \text { population } \\
\text { growth in } 2006 \\
\text { to } 2013 . \text { This } \\
\text { kind of growth } \\
\text { will be one of } \\
\text { moderate } \\
\text { transformation } \\
\text { characteristics. }\end{array}$ & $\begin{array}{l}\text { Just like } \\
\text { population } \\
\text { growth } \\
\text { factor, } \\
\text { housing } \\
\text { growth } \\
\text { moderate } \\
\text { level is } \\
\text { determined } \\
\text { by the } \\
\text { number of } \\
\text { housing } \\
\text { growth in } \\
2013 \text { with } \\
\text { total number } \\
\text { positioned in } \\
\text { between } 25 \% \\
\text { to } 50 \% \text { more } \\
\text { than } 2006 \\
\text { housing } \\
\text { number. }\end{array}$ & $\begin{array}{l}\text { The land use } \\
\text { transformation in } \\
\text { moderate level have } \\
25 \% \text { to } 50 \% \text { more } \\
\text { number of non farm } \\
\text { uses in } 2013 \text { compared } \\
\text { to the total number of } \\
\text { non farm uses in } 2006 \text {. }\end{array}$ & $\begin{array}{ll}\text { - } & \text { Ngasem } \\
\text { Village } \\
\text { - } \quad \text { Bolon } \\
\text { Village } \\
\text { - } \text { Malangji } \\
\text { wan } \\
\text { Village } \\
\text { - Paulan } \\
\text { - Village } \\
\text { Gawana } \\
\text { n Village } \\
\text { Gajahan } \\
\text { Village }\end{array}$ \\
\hline $\begin{array}{l}\text { High } \\
\text { Transformation }\end{array}$ & $\begin{array}{l}\text { High } \\
\text { transformed } \\
\text { villages have } \\
\text { more than } 50 \% \\
\text { additional } \\
\text { number of } \\
\text { inhabintant in } \\
2013 \text { compared } \\
\text { to seven years } \\
\text { ago in } 2006 .\end{array}$ & $\begin{array}{l}\text { It also has } \\
\text { more than } \\
50 \% \text { growth } \\
\text { in term of } \\
\text { housing } \\
\text { number in } \\
2006 \text { to } 2013 .\end{array}$ & $\begin{array}{l}\text { More than } 50 \% \text { farm } \\
\text { uses have swifted in } \\
\text { non farm uses in seven } \\
\text { years (2006-2013). }\end{array}$ & $\begin{array}{ll}\text { - } & \text { Blulukan } \\
\text { - } & \text { Killage } \\
& \text { Klodran } \\
\text { - } & \text { Gillage } \\
\text { n Village }\end{array}$ \\
\hline
\end{tabular}

Sources: Observation, 2014 


\section{Social Economic Transformation Analysis}

Land use transformation in Colomadu Sub-district has brought some transformations in social and economic condition especially when migration series happening as the result of new settlement development. It is also kind of heterogeneous as it was stated by Narain and Nischal in 2007 about peri-urban characteristic in term of social and economic.

In Colomadu Sub-district itself there are some differences in social economy conditions between people who live in residential estate area and unplanned residential or usually called as kampong in Bahasa. Those differences include some basic information like characteristics and activities of the people. Both areas will be compared in the chart, graph, and map form. It is the result of questionnaire compilation data.

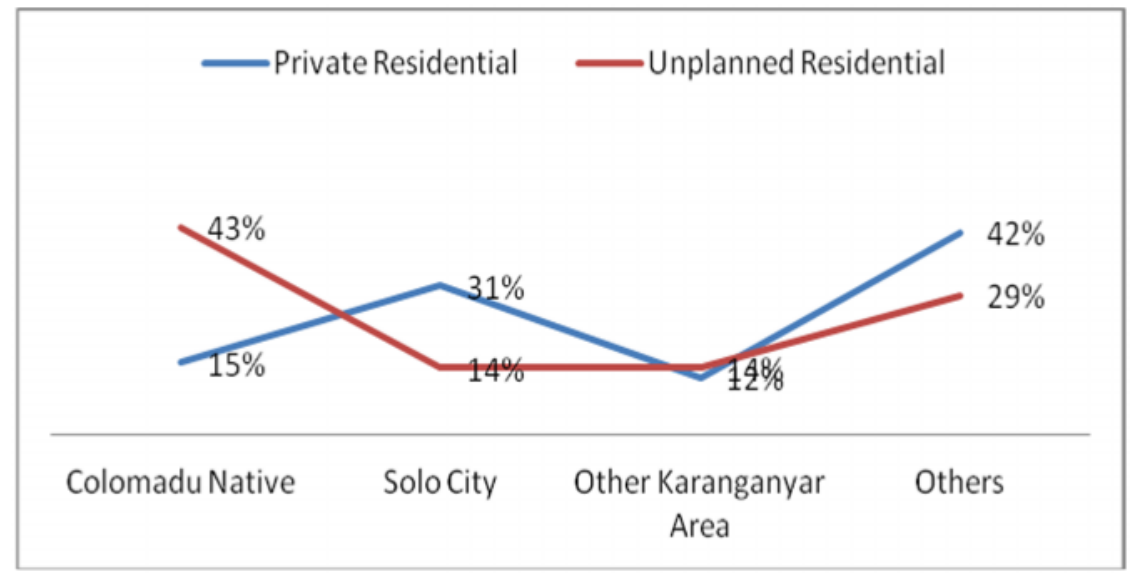

Sources: Observation, 2014

FIGURES 6

PEOPLE ORIGIN GRAPH

From the pie charts above it can be identified that people who live in residential estate come from other regions. They do not only come from Solo but also some other area like Sragen, Klaten, even Bandung, Jakarta, and Samarinda. In total there are 31\% of the respondent coming from Solo or Surakarta and $42 \%$ of them come from other area. Colomadu native people itself only occupy $15 \%$ of residential estate houses. While the rest $12 \%$ come from other sub-district in Karanganyar.

The shifting of occupation is the impact of land use transformation. Most farmers have given up on managing their farm land. It is understandable since the position of farmers have been difficult. The accessto water is one of the reasons because the water did not manage to reach the farm landin some village such as Gawanan. Farmers have to find water, since the garbage block the drainage. In addition, some developers even choose to close drainage which make it even more difficult to clean up. The statistical bureau time series data in occupation show the same conclusion.

TABLE 3

COLOMADU SUB-DISTRICT OCCUPATION DATA

\begin{tabular}{|l|r|r|r|r|r|}
\hline Occupation & \multicolumn{1}{|c|}{2003} & 2006 & 2009 & 2010 & 2013 \\
\hline Farmer & 1.602 & 1.475 & 1.419 & 1.404 & 908 \\
\hline
\end{tabular}




\begin{tabular}{|l|r|r|r|r|r|}
\hline \multicolumn{1}{|c|}{ Occupation } & \multicolumn{1}{c|}{2003} & \multicolumn{1}{c|}{2006} & \multicolumn{1}{c|}{$\mathbf{2 0 0 9}$} & \multicolumn{1}{c|}{$\mathbf{2 0 1 0}$} & $\mathbf{2 0 1 3}$ \\
\hline Petty Farmer & 1.488 & 1.244 & 1.153 & 1.124 & 1.465 \\
\hline Fisherman & - & - & - & - & - \\
\hline Entrepreneur & 469 & 805 & 860 & 893 & 463 \\
\hline Industrial Labor & 4.627 & 7.045 & 7.209 & 7.278 & 1.900 \\
\hline Construction Worker & 3.312 & 3.298 & 3.352 & 3.369 & 1.277 \\
\hline Trader & 1.433 & 1.695 & 1.795 & 1.819 & 972 \\
\hline Transportation Services & 377 & 442 & 433 & 428 & 314 \\
\hline Civil Servant/TNI/POLRI & 2.833 & 2.918 & 2.978 & 2.966 & 3.033 \\
\hline Pensionary & 1.336 & 1.412 & 1.466 & 1.498 & 1.605 \\
\hline Others & 25.207 & 25.606 & 30.019 & 30.403 & 1.814 \\
\hline
\end{tabular}

Sources : BPS of Karanganyar District, 2003, 2006, 2009, 2010 and 2013

The map series above are the economic facilities number maps in each village in 2006 and 2013. In 2006, there were two villages that reached high number in economic facilities with more than 101 units. Those two villages were Malangjiwan and Baturan Village, once again the early developed village as predicted. In the moderate number, there were seven villages; most village in Colomadu were in this level. The other two, Gajahan and Ngasem Village had the least number of economic facilities. The result is not far from the other data especially the development's data.

In 2013, five villages were in high number of economic facilities while the other six thatin moderate level. It means thatGajahan and Ngasem Village had more facilities compared to 2006's data. Gedongan, Blulukan, and Klodran Village also increased rapidly and reached high number of economic facilities. The other village stayed the same as seven years ago.The following map helps us understand the growth of each village in terms of economic facilities.

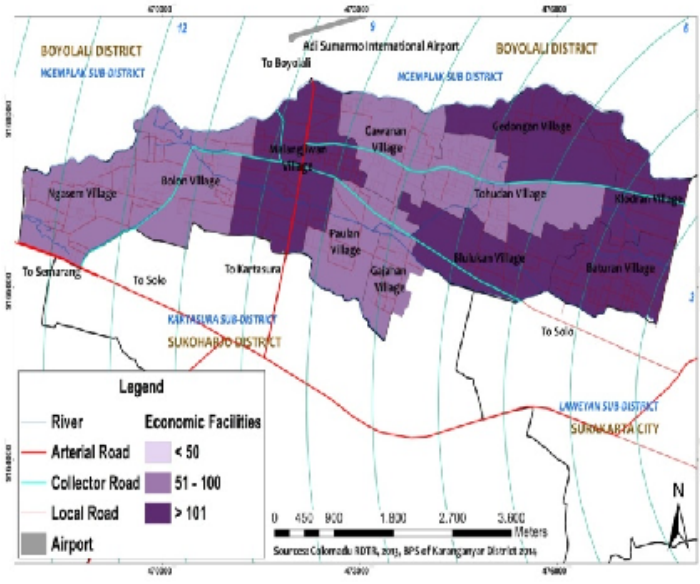

Source: Research Analysis, 2014

FIGURES 7

THE GROWTH OF ECONOMIC FACILITIES IN 2006 TO 2013

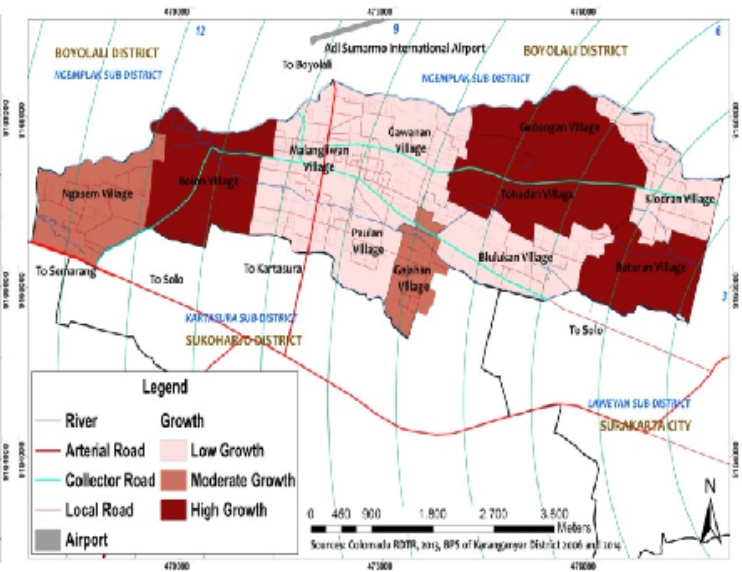

Source: Research Analysis, 2014

FIGURES 8

THE GROWTH OF INDUTRIAL FACILITIES IN $2006-2013$

The development of industrial activities in Colomadu is very fast. Nowadays, Gawanan and Gedongan Village has the highest percentage in industrial activities growth while Malangjiwan 
and Gajahanare following in the moderate growth. The rest arefollowing in low growth level. Although the growth is divided into three classes but actually all villages have reached more than $100 \%$ growth. The lowest one is $200 \%$ while the highest is $8400 \%$ which means the number of industrial activities today in gedongan is 84 times bigger than in 2006. In fact, there was no industrial activities in Gedongan back in 2006 while today there are 84 industrial units in this village. Below are some pictures of industrial activities in Colomadu. There are three industries located in Bolon, Malangijiwan, and Gawanan Village. The one in Malangjiwan is the oldest one.

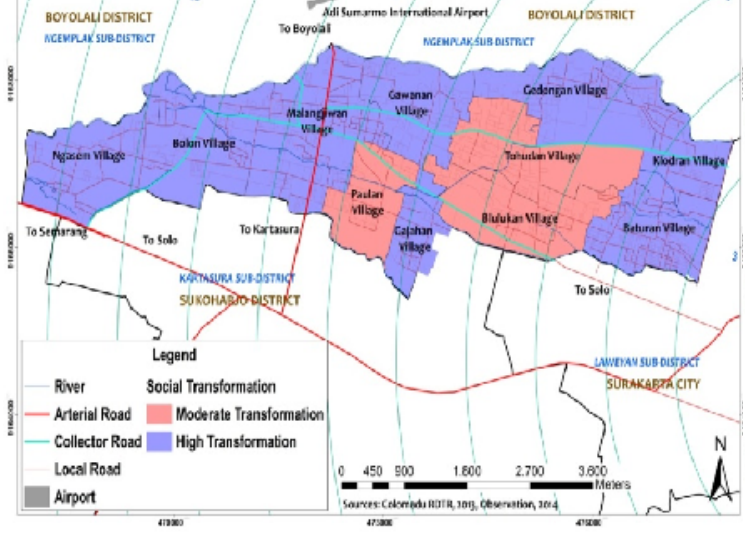

Source: Research Analysis, 2014

\section{FIGURES 9} THE SOCIAL TRANSFORMATION

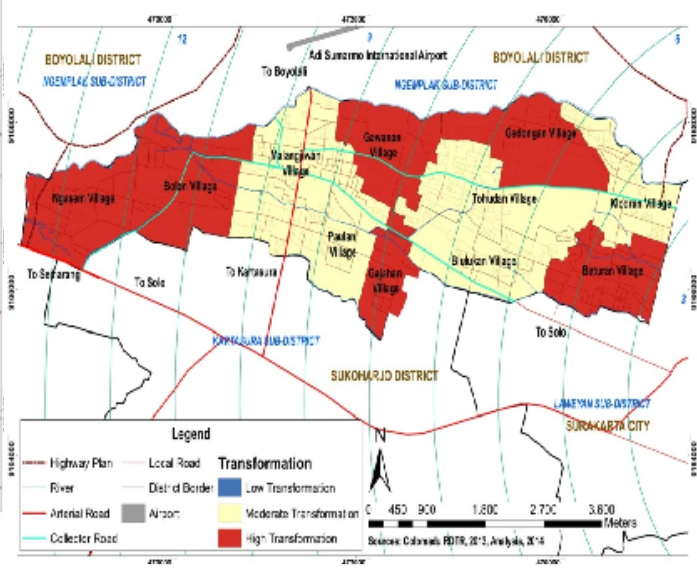

Source: Research Analysis, 2014

FIGURES 10 THE SOCIAL ECONOMIC TRANSFORMATION

Social transformation of Colomadu Sub-district has been summarize in the map above. The questionnaire data compilation shows that three villages in Colomadu have moderate level of social transformation while the restare in high levelof transformation. There isn't any village in low level of social transformation. From social transformation,the social changes in relation to in-migration condition in this sub-district can be identified. Moderate level of transformation represents 50:50 condition of social characteristic in some villages. It meansthat there is a mix of 50\% native people and $50 \%$ of migrants that come from other areas, sub-districts, or districts outside Colomadu. High level of social transformation means $75 \%$ of its inhabitant consists of migrants people while the rest $25 \%$ are native people of Colomadu. From this result, it can be concluded that Colomandu has a high level of transformation in average because only three villages have moderate level of social transformation while the rest eight villages have high level of transformation.

TABLE 3

COLOMADU SUB-DISTRICT SOCIAL ECONOMIC TRANSFORMATION TYPOLOGY

\begin{tabular}{|c|c|c|c|c|}
\hline Typology & $\begin{array}{l}\text { Industrial } \\
\text { Facilities }\end{array}$ & $\begin{array}{c}\text { Economic } \\
\text { Facilities } \\
\text { Growth }\end{array}$ & Social Changes & Village \\
\hline $\begin{array}{l}\text { Low } \\
\text { Transformation }\end{array}$ & $\begin{array}{l}\text { The number of } \\
\text { industrial } \\
\text { activities has } \\
\text { been increasing } \\
\text { less than } 500 \% \text {. It } \\
\text { is quite high } \\
\text { because the } \\
\text { average industrial } \\
\text { activities growth }\end{array}$ & $\begin{array}{l}\text { In term of } \\
\text { economic } \\
\text { facilities the } \\
\text { low growth } \\
\text { level villages } \\
\text { have small } \\
\text { number of } \\
\text { growth with } \\
\text { only less than }\end{array}$ & $\begin{array}{l}\text { Migration is the main } \\
\text { implication here to } \\
\text { understanf the social } \\
\text { changes. In this level } 75 \% \\
\text { of the village inhabitant is } \\
\text { native people of } \\
\text { Colomadu, while the rest } \\
25 \% \text { is migrants that come } \\
\text { from other area. }\end{array}$ & - \\
\hline
\end{tabular}




\begin{tabular}{|c|c|c|c|c|}
\hline Typology & $\begin{array}{l}\text { Industrial } \\
\text { Facilities }\end{array}$ & $\begin{array}{c}\text { Economic } \\
\text { Facilities } \\
\text { Growth }\end{array}$ & Social Changes & Village \\
\hline & $\begin{array}{l}\text { in Colomadu } \\
\text { since } 2006 \text { is } \\
2000 \% \text { Low } \\
\text { growth village } \\
\text { such as } \\
\text { Malangjiwan, } \\
\text { Gawanan, } \\
\text { Blulukan, Paulan } \\
\text { and Klodran only } \\
\text { have small } \\
\text { number of } \\
\text { additional } \\
\text { industrial ativities } \\
\text { in 2013. }\end{array}$ & $\begin{array}{l}25 \% \text { growth in } \\
2006 \text { to } 2013 \text {. }\end{array}$ & & \\
\hline $\begin{array}{l}\text { Moderate } \\
\text { Transformation }\end{array}$ & $\begin{array}{l}\text { This level has } \\
\text { industrial facilities } \\
\text { growth between } \\
500 \% \text { to } 1000 \% \text { in } \\
2006 \text { to } 2013 \text {. }\end{array}$ & $\begin{array}{l}\text { Moderate } \\
\text { level of } \\
\text { economic } \\
\text { facilities } \\
\text { growth is } \\
\text { consists of } \\
\text { some villages } \\
\text { that have } 25 \% \\
\text { to 50\% growth } \\
\text { of economic } \\
\text { facilities based } \\
\text { on } \\
\text { Karanganyar } \\
\text { District } \\
\text { Statistical } \\
\text { Central Bureau } \\
\text { from 2006 to } \\
2013 \text {. }\end{array}$ & $\begin{array}{l}\text { In social changes } \\
\text { moderate level the } \\
\text { inhabitants has shared } \\
50: 50 \text { in term of origin } \\
\text { characteristic. So } 50 \% \text { of } \\
\text { the inhabitant is } \\
\text { Colomadu native, while } \\
\text { the other } 50 \% \text { are migrants } \\
\text { people. }\end{array}$ & $\begin{array}{ll}\text { - } & \text { Tohudan } \\
\text { - } & \text { Village } \\
\text { Blulukan } & \text { Village } \\
\text { - } & \text { Malangji } \\
\text { wan } \\
\text { Village } \\
\text { - } \quad \text { Paulan } \\
\text { - } \text { Village } \\
\text { Klodran } \\
\text { Village }\end{array}$ \\
\hline $\begin{array}{l}\text { High } \\
\text { Transformation }\end{array}$ & $\begin{array}{l}\text { Industrial } \\
\text { facilities growth } \\
\text { in this level is the } \\
\text { highest with } \\
\text { more than } 1000 \% \\
\text { growth from } \\
\text { 2006 until } 2013 .\end{array}$ & $\begin{array}{l}\text { The level of } \\
\text { economic } \\
\text { facilities } \\
\text { growth here } \\
\text { has been } \\
\text { reaching more } \\
\text { than } 50 \% \text { in } \\
\text { total in } 2013 \\
\text { from } 2006 .\end{array}$ & $\begin{array}{l}\text { All villages that have high } \\
\text { transformation in social } \\
\text { aspect have } 75 \% \text { inhabitant } \\
\text { come from another area } \\
\text { or migrants, the rest } 25 \% \\
\text { are native people of } \\
\text { Colomadu. }\end{array}$ & $\begin{array}{ll}\text { - } & \text { Ngasem } \\
\text { - } & \text { Village } \\
& \text { Bolon } \\
& \text { Village } \\
\text { - } & \text { Gedonga } \\
\text { n Village } \\
\text { - Gawanan } \\
\text { - } \quad \text { Village } \\
\text { Gajahan } \\
\text { - } \text { Village } \\
\text { Baturan } \\
\text { Village }\end{array}$ \\
\hline
\end{tabular}

Sources: Observation, 2014

TABLE 4

FINDING

\begin{tabular}{|c|l|c|c|l|}
\hline No & Village & $\begin{array}{c}\text { Land Use } \\
\text { Transformation }\end{array}$ & $\begin{array}{c}\text { Social Economic } \\
\text { Transformation }\end{array}$ & Transformation Main Factor \\
\hline 1 & Ngasem & Moderate Level & High Level & $\begin{array}{l}\text { It located in the most west } \\
\text { part of Colomadu but it still } \\
\text { has high number of farm land. } \\
\text { Most people who lived here } \\
\text { works in Colomadu and } \\
\text { Kartasura. Once Tentara } \\
\end{array}$ \\
& & & & \begin{tabular}{l} 
Pelajar street become bigger \\
\hline
\end{tabular} \\
\hline
\end{tabular}




\begin{tabular}{|c|c|c|c|c|}
\hline No & Village & $\begin{array}{c}\text { Land Use } \\
\text { Transformation }\end{array}$ & $\begin{array}{l}\text { Social Economic } \\
\text { Transformation }\end{array}$ & Transformation Main Factor \\
\hline & & & & $\begin{array}{l}\text { the transformation will be } \\
\text { faster. Social economically } \\
\text { many migrants have move } \\
\text { here especially that works as a } \\
\text { trader in Kartasura. }\end{array}$ \\
\hline 2 & Bolon & Moderate Level & High Level & $\begin{array}{l}\text { Social economically it is high } \\
\text { because of many new } \\
\text { industrial activities built here. } \\
\text { In the other side, it is } \\
\text { moderate in land use } \\
\text { transformation because of } \\
\text { the main access here is a local } \\
\text { level street called Tentara } \\
\text { Pelajar street that quite small. } \\
\text { It is also located far from Solo } \\
\text { as main attraction of workers } \\
\text { and migrants, and as the most } \\
\text { decent facilities located. In } \\
\text { near future the development } \\
\text { will be higher because bolon } \\
\text { has the highest number of } \\
\text { farm land compared to } \\
\text { another village. The land price } \\
\text { is also low. }\end{array}$ \\
\hline 3 & Malangjiwan & Moderate Level & Moderate Level & $\begin{array}{l}\text { It is one of the early } \\
\text { developed village but it } \\
\text { located right in the } \\
\text { intersection of Adi Sucipto } \\
\text { and Adi Sumarmo Street so } \\
\text { that it is strategic location for } \\
\text { them who work in Solo, } \\
\text { Kartasura, or Boyolali. }\end{array}$ \\
\hline 4 & Paulan & Moderate Level & Moderate Level & $\begin{array}{l}\text { It is the latest developed area } \\
\text { based on interview because } \\
\text { of its high land prices. } \\
\text { Developer started to exploit } \\
\text { this village in } 2013 \text {. So that is } \\
\text { why the transformation in } \\
2006 \text { to } 2013 \text { still moderate. }\end{array}$ \\
\hline 5 & Gajahan & Moderate Level & High Level & $\begin{array}{l}\text { Gajahan has the highest } \\
\text { average land price just like } \\
\text { Paulan and become the latest } \\
\text { developed one so that in } 2006 \\
\text { to } 2013 \text { the transformation in } \\
\text { Gajahan is only moderate. }\end{array}$ \\
\hline 6 & Blulukan & High Level & Moderate Level & $\begin{array}{l}\text { Blulukan has high land price } \\
\text { but indeed accesible } \\
\text { especially from Solo since } \\
\text { most people here works in } \\
\text { Solo. Solo where people } \\
\text { choose to look for good } \\
\text { facilities and shops. It is } \\
\text { passed through by Adi } \\
\text { Sucipto street a primary } \\
\text { collector level street. }\end{array}$ \\
\hline 7 & Gawanan & Moderate Level & High Level & $\begin{array}{l}\text { Although Gawanan Village } \\
\text { passed through by two main } \\
\text { street, but the transformation } \\
\text { is moderate. It is because one }\end{array}$ \\
\hline
\end{tabular}




\begin{tabular}{|c|c|c|c|c|}
\hline No & Village & $\begin{array}{c}\text { Land Use } \\
\text { Transformation }\end{array}$ & $\begin{array}{l}\text { Social Economic } \\
\text { Transformation }\end{array}$ & Transformation Main Factor \\
\hline & & & & $\begin{array}{l}\text { of the oldest residential } \\
\text { estate in Colomadu located } \\
\text { here. The availability of the } \\
\text { land is also low so that today } \\
\text { there are smaller number of } \\
\text { resdential developement } \\
\text { happened here. }\end{array}$ \\
\hline 8 & Gedongan & High Level & High Level & $\begin{array}{l}\text { Gedongan with its low land } \\
\text { prices become developer } \\
\text { favorit nowadays. It also only } \\
\text { five to six kilometers away } \\
\text { from Solo with Adi Sumarmo } \\
\text { as the main access. The } \\
\text { avalability of the land is also } \\
\text { high, so that it attract many } \\
\text { developer. }\end{array}$ \\
\hline 9 & Tohudan & Low Level & Moderate Level & $\begin{array}{l}\text { Tohudan is the } \\
\text { neighbourhood area } \\
\text { Gedongan. It located } \\
\text { alongside Adi Sumarmo } \\
\text { Street. Although Tohudan had } \\
\text { the same access as Gedongan } \\
\text { but the land price is higher in } \\
\text { average. That is why the land } \\
\text { use transformation of } \\
\text { Tohudan is lower than } \\
\text { Gedongan. }\end{array}$ \\
\hline 10 & Baturan & Low Level & High Level & $\begin{array}{l}\text { Baturan has the lowest } \\
\text { number of non-built-up area. } \\
\text { It is the early developed } \\
\text { village that adeveloping in the } \\
\text { early } 1990 \text {, so that today the } \\
\text { land use transformation is } \\
\text { low. But as it located close to } \\
\text { Solo and has the high level of } \\
\text { social economic } \\
\text { transformation as most of the } \\
\text { people works in Solo. }\end{array}$ \\
\hline 11 & Klodran & High Level & Moderate Level & $\begin{array}{l}\text { Klodran located only } 5 \mathrm{~km} \\
\text { away to Solo. So, many } \\
\text { worker that works in Solo see } \\
\text { it as a strategic location for } \\
\text { residential area. It also } \\
\text { located alongside Adi } \\
\text { Sumarmo Street, one of the } \\
\text { main street in Colomadu. }\end{array}$ \\
\hline
\end{tabular}

Sources: Analysis, 2014

\section{CONCLUSION}

- Colomadu Sub-district is a rural-urban interface area which is administratively part of Karanganyar District. In fact, it is located closer to Solo rather than to Karanganyar as the authorizingdistrict.

- The existences of Adi Sumarmo International Airport and Solo City havebeen influencing the development of Colomadu as theyattracts many visitors and investors. Today's 
development of Colomadu Sub-districtis dominated by residential and commercial development.

- Land use transformation in this area has reach moderate and high level of transformation with high population growth, housing growth and farm to non-farm use transformation. High level of land use transformation can be foundKlodran, Blulukan and Gedongan Village, while the area with moderate level include Ngasem, Bolon, Malangjiwan, Gawanan, Gajahan, and Paulan Village. Furthermore Baturan and Tohudan Village are two villages with low level of transformation.

- Baturan and Malangjiwan are the early developed villages. Baturan is the closest village to Solo, andin the other side Malangjiwan is the capital village of Colomadu with old sugar company and air force academy, camp and settlement.

- As for Tohudan, which is categorized as low level land use transformation, the development is indeed low as the result of higher land prices.

- Klodran Village's development is the direct impat of Baturan's development.

- In terms of social transformation, the result shows that most villages in Colomadu have reached high level of social economic transformation. In details there are five villages in moderate level of transformation including Malangjiwan, Paulan, Blulukan, Tohudan and Klodran Village. In the other side, there are six villages in high level of social economic transformation including Ngasem, Bolon, Gawanan, Gajahan, Gedongan, and Baturan Village.

- In terms of prosperity level, all villages in Colomadu have high growth in the KS III+ level of prosperity except for Malangjiwan Village which only has $10 \%$ of growth. While in the KS III level. Only Paulan Villagehave experienced dropping number by $50 \%$, furthermore, other level conditions are different for each village. In the most villages, the low prosperity level tends to be dropping except for Gawanan Village with $67 \%$ rise and Blulukan with a stable numberof propsperity level since 2006.

- Migration and fertility data showthe transformation of social condition from rural to urbanareas. In most villages, the number of fertility is stabel although the population number is gradually increasing.

- Baturan Village has a unique condition as it has low level of land use transformation, but in terms of social economic transformation, it has high levelof transformation.

- As for Malangjiwan Village, social economic transformation has reached high level before 2000, just the same as land use transformation. Thus, nowadays, the social economic transformation level of Malangjiwan only reaches moderate level. It is because there is decreasing number of economic growthin Malangjiwan as the village market had been closed. It meansthat raditional market is not the core ofdevelopment place now.

- Paulan and Gajahan Village would be the most potential village to reach high social economic transformation in the future as they started developing earlier than other villages.

- Solo City, Kartasura Village as part of Sukoharjo District, and Boyolali District are three important regions that haveinfluenced the development of Colomadu.

- Solo is kind of attractive for Colomadu Sub-district inhabitants because of $42 \%$ from total respondents work in Solo while the rest $68 \%$ workin Colomadu, Sukoharjo, Boyolali, and other areas.

\section{REFERENCES}

Artiningsih. 2011. Kajian Peluang Jalur Sepeda Kota Semarang. Semarang Local Government: Semarang. 
Dutta, Venkatesh. 2012. Land Use Dynamics and Peri-urban Growth Characteristics: Reflections on Master Plan and Urban Suitability from a Sprawling North Indian City. Environment and Urbanization Asia 2012, 3:277.

Kabupaten Karanganyar Statistical Central Bureau 1990. Central Java Statistical Bureau, 2010. Kabupaten Karanganyar Statistical Central Bureau 2003. Central Java Statistical Bureau, 2011. Kabupaten Karanganyar Statistical Central Bureau 2006. Central Java Statistical Bureau, 2006. Kabupaten Karanganyar Statistical Central Bureau 2011. Central Java Statistical Bureau, 2010. Kabupaten Karanganyar Statistical Central Bureau 2012. Central Java Statistical Bureau, 2011. Kabupaten Karanganyar Statistical Central Bureau 2014. Central Java Statistical Bureau, 2014. Kecamatan Colomadu Statistical Central Bureau 2006. Central Java Statistical Board, 2006. Kecamatan Colomadu Statistical Central Bureau 2009. Central Java Statistical Board, 2009. Kecamatan Colomadu Statistical Central Bureau 2010. Central Java Statistical Board, 2010. Kecamatan Colomadu Statistical Central Bureau 2011. Central Java Statistical Board, 2011. Kecamatan Colomadu Statistical Central Bureau 2014. Central Java Statistical Board, 2014. Mc Gee, Terry. 2005. Distinctive Urbanization in the Peri-urban regions of East and Southeast Asia Renewing the Debate. Jurnal Perencanaan Wilayah dan Kota, Vol.16/No.1, hal 3955 .

Narain, Vishal and Nischal, Shilpa. 2007. The Rural-urban interface in Shahpur Khurd and Karnera, India. Enviroment and Urbanization 2007, 19:261.

Wu, Kai-ya and Zhang, Hao. 2011. Land Use Dynamics, Built-up Land Expansion Patterns, and Driving Forces Analysis of Fast-growing Hangzhou Metropolitan Area, Eastern China (1978-2008). Applied Geography 34 (2012), 137-145. 